\title{
REBELLIOUS WOMEN IN THE BLACK FREEDOM STRUGGLE
}

\author{
Monica Maria Tetzlaff
}

Jeanne Theoharis. The Rebellious Life of Mrs. Rosa Parks. Boston: Beacon Press, 2013. xvi + 320 pp. Photographs, notes, and index. \$27.95.

Barbara Ransby. Eslanda: The Large and Unconventional Life of Mrs. Paul Robeson. New Haven: Yale University Press, 2013. xiii + 373 pp. Photographs, chronology, notes, bibliography, and index. $\$ 35.00$.

From Montgomery, Alabama, to the United Nations, women activists promoted the black freedom struggle in the mid-twentieth century, and scholarly biographies of their impact have been emerging since around 2000. ${ }^{1}$ Two recent biographies of Rosa Parks and Eslanda Robeson break new ground in deepening our understanding of gender and the "long history" and international scope of the Civil Rights Movement.

While it will come as no shock that Eslanda Robeson, activist journalist and anthropologist, was a radical like her husband, Paul Robeson, The Rebellious Life of Mrs. Rosa Parks may surprise some readers. Both women had associations with the Civil Rights Movement led by Dr. Martin Luther King, Jr., black nationalism, the peace movement, and the left wing of the union movement. Their biographers, Barbara Ransby and Jeanne Theoharis, are both noted civil rights historians who have argued for the "long civil rights movement" and have placed women at the center, rather than the margins of their analysis.

The result is a rich, gendered view of the long civil rights movement and an examination of the way we view black women activists in our culture. Some of the most important analysis in Theoharis' The Rebellious Life, is her examination of Rosa Parks as a symbol and her critique of that symbolism. Like Martin Luther King, Jr., who often remains frozen in time giving the "I Have a Dream" speech at the 1963 March on Washington, Rosa Parks has been frozen standing on a bus in Montgomery in 1955, refusing to give up her seat. As Theoharis points out, Parks has often been portrayed as a quiet seamstress who was tired that day: an "accidental heroine" who acted as an individual and showed the world the flaw of racism in American democracy, so it could be corrected. Her own rebelliousness in confronting racism through 
collective organizing in the NAACP, the Brotherhood of Sleeping Car Porters, and Highlander Folk School is usually left out. Omitted also is her suffering from this stand and the intense white reprisals-both economic and physically threatening - that drove her out of Montgomery. The many decades of her political life after moving to Detroit, her participation in the Black Power movements in Detroit and nationally, her opposition to the Vietnam War, and her support for nuclear disarmament and the anti-apartheid movement have been virtually invisible. Yet there she stood, as Theoharis writes, "hidden in plain sight" (p. xi).

Class and gender analysis are important in both these biographies. Theoharis' subject preferred to be called Mrs. Parks, and that is how the author refers to her throughout much of the book and (with the addition of her first name) in the title. Rosa Parks was a working-class woman, with all the disadvantages (and advantages of insight) that that position entails in American life. Perhaps the most painful part of being a working-class woman for Parks was that she was not considered qualified enough to have a position with the Montgomery Improvement Association, which received hundreds of thousands of dollars in donations during and after the bus boycott. She herself lost her job at the department store where she had been an assistant tailor (not the more feminized title "seamstress"). As a result, she fell into destitution. As a married woman without children, many assumed that her husband was supporting her, but due to his ill health and the economic retaliation, he too suffered from the actions of segregationist whites.

Theoharis is careful to be fair to Raymond Parks and stresses that Rosa Parks loved him deeply and valued his support and companionship as a fellow radical. She points out that Rosa McCauley thought of him as "the first real activist" whom she had ever met (p. 13). Raymond Parks was organizing support for the Scottsboro Boys in the 1930s when he and Rosa McCauley first became acquainted. In Montgomery and Detroit, he worked as a barber, but he had frequent health problems. He and Rosa Parks supported her mother, which added to their economic burden.

Private relationships, especially marriages, are tricky in women's biographies. Women who live full and engaged lives with other human beings also, of course, have full and complicated lives with their spouses; yet to make too much of this primary relationship is to reduce women biographical subjects to a traditional role of wife. Here the question of sources as well as class becomes key. Theoharis did not have the rich resource of dozens of diaries and thousands of letters and papers that Ransby had at her disposal for the Robesons. Sadly, because of a judge's order, the majority of Rosa Parks' papers and ephemera are under lock and key in a New York warehouse, awaiting a six-million-dollar buyer. (Payment will be split between competing heirs to Rosa Parks' estate.) Ransby delves into Eslanda Robeson's sexuality and her 
open marriage to Paul Robeson in a way that Theoharis does not with her subject. Perhaps this decision is based on a lack of sources, or perhaps it is the distance she chooses to maintain from Mrs. Parks. As Theoharis writes about Parks herself, "she safeguarded a modicum of privacy, limiting which aspects of her political and personal biography she reported" (p. 2).

Parks' background and pre-bus-boycott life of activism will be of great interest to readers. Rosa McCauley and her brother Sylvester grew up in rural Alabama, spending a great deal of time with their grandparents, while her mother taught school in another town and her father lived a "wandering" life as a stonemason, mostly in the North. Theoharis writes that Rosa Parks "grew up in a home full of love" and that she had early exposure to race activism through her formerly enslaved grandfather, who had joined Marcus Garvey's "pan-Africanist Universal Negro Improvement Association" (p. 3). Parks recalled sitting up at night and keeping watch over the house with her grandfather, who had a rifle for self-defense because black people who stood up for their rights were "flogged or found dead" due to Klan violence (p. 3). This tradition of armed self-defense of one's own home was also the choice of many other Southern African American activists' who would remain nonviolent in direct actions against segregation. This seeming dichotomy might be confusing to later observers, but made sense to Parks' grandparents and others in their circumstances.

Rosa Parks' mother's commitment to her daughter's further education took Rosa to Miss White's Montgomery Industrial School for girls, where she met lifelong friend Johnnie Carr, who was later with her in the NAACP. The education provided by the Northern white women who founded this school for African American teenage girls included respect for their rights in the Constitution as well as practical skills like cooking and sewing.

Parks' pre-boycott life involved years of frustratingly fruitless activism with the NAACP. She was inspired by E. D. Nixon, who was a working-class leader of the Brotherhood of Sleeping Car Porters and started the Montgomery Voter's League. Parks tried to register to vote numerous times, beginning in 1943. Parks was one of the first African Americans to speak up for Mrs. Recy Taylor, who was gang-raped by six white men in Abbeville, Alabama, in 1944. She reported the crime, but the white police did nothing to charge her assailants. Parks helped form the Committee for Equal Justice for Mrs. Recy Taylor and was gratified when the Pittsburgh Courier ran a story and prominent black leaders such as Adam Clayton Powell joined the committee. Still there was no justice for Taylor in court and, eventually, Parks helped her move to Montgomery because of threats and harassment from whites.

Theoharis also chronicles Parks' work with the youth branch of the NAACP, particularly her decision to take them on the integrated Freedom Train, which displayed documents from American history to young visitors in 1947. She 
received threatening and harassing phone calls as a result, but she persisted in her activism, supporting young black women who refused to give up their seats on the segregated Montgomery buses. Yet they could not find community support for their actions because they were not considered the ideal plaintiffs. Finally, on that historic Thursday, December 1, 1955, Parks decided not to give up her own seat on a Montgomery bus and was arrested and jailed, alone but determined. The fact that the black community did rally around her and that the Women's Political Council, together with African American ministers, led a successful one-day boycott surprised and thrilled her. She and Raymond did everything they could to keep it going through the next eleven months.

One of the most inspired parts of the biography concerns what Rosa Parks did not say but might have. This is an issue for the biographer of a shy person whom the media consigned to a symbolic role. How do you analyze your subject's political thought when she was rarely given a chance to speak for herself? As Theoharis writes, "Parks was lauded for her role as a heroine, but not consulted for her vision of the struggle and subsequent political strategy" (p. 93). In fact, though she was featured seated in the front of the church at one of the first Montgomery mass meetings, she was told when the question of speaking came up, "'Why you've said enough'." Theoharis goes on to capture the twenty-first-century reader's outrage over this condescending comment by writing:

If she had gotten to speak, Parks might have connected the injustice on the bus to the travesties of Scottsboro, the brutal rapes of Recy Taylor and Gertrude Perkins, the murder of Emmett Till. . . . If she had gotten to speak, she might have linked her stand to the courageous work of the Highlander Folk School, to the actions of her own Youth Council at the downtown library. . . . She might have said that this movement was a long time in coalescing, but what a joyful and holy day it was now that it had come. All this she knew and might have said-or much more. But she did not get to speak. [p. 93]

It is Theoharis' task to allow Rosa Parks to speak at last, so what does she say? At first she was able to say little because she was struggling for her survival. During this time, Theoharis highlights Parks' friendship with Virginia Durr, a white leftist who understood Parks' economic plight and pleaded her case for a civil rights job more strongly than anyone else. Yet this relationship was necessarily complicated by her race and the fact that Durr was sometimes Parks' employer. She could not find a job for Parks in Montgomery, and in 1959, Rosa and Raymond Parks and Leona McCauley moved to Detroit to be near Mrs. Parks' brother Sylvester.

Parks took part in the movement against Northern racism in Detroit. She experienced the same struggle that many African American women did finding remunerative and dignified work. Parks eventually took a job at the Stockton 
Sewing Company, working long hours sewing aprons and skirts. She was involved in political life, working to elect African Americans to office, and she finally was offered a meaningful career as a staffer for Congressman John Conyers in his Detroit office. Parks became an important aunt to the many nieces and nephews in her extended family and was deeply involved in the local activities for community improvement in her African American neighborhood, which was considered ground zero of the Detroit uprising in 1967.

Perhaps most startling to some will be Rosa Parks' embrace of black nationalism and Malcolm X. Parks participated in events at Rev. Albert Cleage's black nationalist Central Congregational Church, known as the Shrine of the Black Madonna. She attended Cleage's Grassroots conference in 1963 and 1965 and met Malcolm X, who was the featured speaker "and they became a bit friendly," as Theoharis writes (p. 209). Parks worked faithfully for African American and African causes until her death, most notably protesting against apartheid in front of the South African embassy in 1985. She became more and more of a symbol in the 1990s and 2000s as she aged and became less active. Unlike Eslanda Robeson, whose family chose not to have a public funeral or memorial, Rosa Parks became the first woman whose body lay in state at the Capital Rotunda when she died in 2005. Theoharis argues that, at this moment, "instead of using the opportunity to illuminate and address current social inequity, the public spectacle provided an opportunity for the nation to lay to rest a national heroine and its own history of racism" (p. $\mathrm{x}$ ). Theoharis' biography is an attempt to right the wrong of this abuse of history.

Rosa Parks was a quilter, and Theoharis uses a quilt metaphor to describe the way that Parks stitched together the whole spectrum of the Civil Rights Movement, from nonviolent direct action to self-defense and Black Power, not rejecting any of these approaches. Though Parks was interviewed about her quilting, it is Theoharis who puts together this quilt metaphor of her politics, and it feels like a bit of a stretch, highlighting the difficulty of writing about a subject who took a stand by participating but did not frequently articulate her views. Theoharis is right to note that Parks practiced dissemblance, as did many African American women, not always putting her views forward in her public statements and therefore remaining elusive to a biographer.

Unlike Rosa Parks, Eslanda Robeson could more likely be called an African American anti-heroine, portrayed in the popular and even the scholarly mind before Barbara Ransby's biography as a pushy wife and a duped or deliberately blind supporter of communism during the Cold War. Ransby covers Eslanda's entire lifespan in traditional biographical format but pays particular attention to the significance of her career as "an anti-colonial crusader and a peace and freedom activist and journalist" (p. 143). Like her more-famous spouse, she was targeted by Senator Joseph McCarthy for her leftist political writings and 
her support of the Soviet Union. Paul Robeson was called to testify in 1946, and in 1953 Eslanda Robeson was called before the U.S. Senate Permanent Subcommittee on Investigations, headed by Senator Joseph McCarthy. Her outraged and yet carefully crafted response to that committee is one of the highlights of Ransby's well-written narrative.

Eslanda Cardozo Goode was influenced in her early life by the story of her maternal grandfather, Francis Lewis Cardozo, a free black South Carolinian who studied at the University of Edinburgh and was state treasurer of South Carolina during Reconstruction. Several members of her family were educators and part of the black elite in Washington D.C. Although her father John Goode was an attorney who supported the family in a middle-class lifestyle, he died when Eslanda was five years old, and her mother had to support her three children. She was able to do this by being a creative entrepreneur in New York City and Chicago, running a salon and managing a beauty consultancy with many wealthy white women as clients. Ransby argues that the elder Eslanda Goode (mother and daughter had the same name) was an influence on her daughter through her self-reliance and also her support for "collective action and radical ideas" including women's rights, black socialists, nationalists, and internationalists (p. 26). In New York City and Chicago, young Eslanda excelled in academics and won a four-year scholarship to the University of Illinois at Urbana, where she majored in chemistry.

In contrast to Theoharis' choice to call her subject Mrs. Parks, Ransby makes the decision to refer to her subject as Essie much of the time, perhaps partly because mother and daughter had the same name, and perhaps also because her spouse, Paul Robeson, is mentioned so often in the same passages. By referring to her as Essie, Ransby brings herself and the reader into the circle of the Robeson's family and friends. Since Ransby's treatment of Robeson is respectful and well-rounded, this naming works, but it is also dependent on Robeson's class status. It would not have seemed as respectful to make the same decision if she were not portraying such an accomplished and relatively privileged black woman.

How did Eslanda come to live her "large and unconventional life"? The time and place of her life, as well as her family, influenced her, as did her hard work, talent, and ambition. Eslanda Goode and her mother moved back to Harlem around 1919. There, Essie finished her degree at Columbia University Teacher's College in 1920 and became the first African American woman to work in the pathology laboratory of Columbia Presbyterian Hospital. Eslanda arrived back in Harlem just in time for the Harlem Renaissance, and she relished the excitement of these heady cultural times for young, educated African Americans in Harlem. She met Paul Robeson in 1919 through mutual friends, and they deepened their relationship when they both took summer classes at Columbia University. Their passion was stormy, as the romance went on and off again, but they decided to elope on August 21, 1921. 
Ransby deftly lays out the story of Essie's vital role in identifying Paul Robeson's talents as a singer and actor and in encouraging him to pursue a career in the performing arts instead of the law. They both took a chance in doing so, but Essie was right that Paul's bass-baritone voice and acting ability were superb. As his manager, she had networking skill, organizational ability, and persistence. Their talents combined to make Paul Robeson the best-known African American in the world through his stage performances in Emperor Jones, All God's Chillun Got Wings, and Othello, as well as in the newly created recording and film industries. In the 1920s and '30s, the Robesons spent considerable time in London, Paris, and also the Soviet Union, where they connected with a network of radical artists and writers including Emma Goldman, Claude McKay, and Max and Elena Eastman.

In 1927, Eslanda gave birth to their only child, Paul Robeson, Jr., born while Paul, Sr., was on a concert tour. Eslanda continued to work as Paul's manager and did some writing on her own, while her mother became a caregiver for Paul, Jr.

Ransby clearly informs the reader that this biography focuses on the political life of Eslanda Robeson, but she sensitively handles her relationship to Paul Robeson, including their decision to have an "open marriage." While the extramarital romances were mostly his, Ransby shows that Eslanda lived a life full of close and varied friendships with both women and men of many cultures and several continents. Regarding her relationship with Paul, Ransby characterizes it as moving from romance to friendship, tied by political passion and parenthood.

In the 1930s, Essie no longer devoted herself mainly to managing Paul's career and became able to express her own thoughts on world affairs in the public sphere. She began by writing fiction, published a biography of Paul, and went on to write more nonfiction, obtaining an interview with Mahatma Gandhi in 1931 and becoming an important published African American anticolonial voice. Essie did graduate coursework at the London School of Economics and came close to completing her Ph.D., but she was more interested in being a public intellectual than an academic. Ransby argues that Robeson "expressed both a leftist Pan-Africanism and an internationalist view of Black identity and politics" (p. 90). During the 1930s, she and Paul also traveled to the Soviet Union, where they spent the early part of 1935. Essie's two brothers moved to the Soviet Union, where they found that racism was less of an impediment than in the United States.

In 1936, Essie fulfilled her long-time dream of traveling to Africa, and she returned again in 1946. She kept detailed notes from her journeys across the continent, describing the lives of rural and working-class women with particular interest. Her main area of anthropological study was the Congo, but she met with African colonial and anticolonial leaders all over the continent. 
In 1945, she published her observations as African Journey and hoped to base a second book on her 1946 trip, although this project did not come to fruition. Nevertheless, she drew on her knowledge to write articles in support of African independence movements and was a leading member of the Council on African Affairs. In 1949, she and Pearl Buck coauthored a book entitled American Argument about politics in the United States and abroad. Essie was becoming more political in other ways, plunging in with Paul to support Henry Wallace and the Progressive Party in the 1948 presidential campaign.

Her major influence in the 1950s was as a writer and speaker. She wrote on global issues for the leftist New World Review, making the newly formed United Nations and the anticolonial struggles there a main topic. When she spoke in public during this era, she was often harassed and threatened by right-wing Americans. At least as disturbing was the fact that the FBI had been surveilling her since 1943. Ransby makes interesting use of the notes on Essie that she obtained through FBI files. Essie and Paul were battered by the Red-baiting campaign against them, especially when their passports were taken away in 1950 because they refused to sign statements that they were not communists. This abridgement of their freedom to travel resulted in a major loss in Paul's earnings, due to his inability to perform abroad.

After the couple regained their right to travel, they spent a number of years overseas, returning in 1963 in time for Essie to author articles supporting the Black Freedom movement. Eslanda Robeson died in 1965, just as the transnational Black Power movement, the New Left, and the women's movement were about to heat up. Although she is careful to write that Essie did not call herself a feminist, Ransby places her in the company of what we now call "Black Left feminists" who promote black women's leadership and women's rights, along with workers' rights around the globe.

Ransby and Theoharis' biographies put their subjects in the context of an African American women's activist network. Theoharis writes of Ella Baker and Septima Clark as being Rosa Parks' mentors. Ransby writes of Robeson's many friendships with left-wing women worldwide. Both Parks and Robeson spoke out for other African American women who were victims of rape. Although these stands have been eclipsed by antilynching and other aspects of the Civil Rights Movement, Theoharis and Ransby see them as important.

In both of these biographies, the authors keep the reader turning pages, wanting to know what Mrs. Parks and Essie Robeson will do next to further their causes or take care of themselves and their families in times of strain and opposition. Theoharis and Ransby both do a good job of incorporating analysis with narratives, moving us through their subjects' lives roughly chronologically, while focusing at the same time on themes such as support for Africa. Their biographies of these two rebellious women show us that the global struggle for racial and economic justice went hand-in-hand in twentieth-century America. 
Monica Maria Tetzlaff is an associate professor of history at Indiana University South Bend. She is the author of Cultivating a New South: Abbie Holmes Christensen and the Politics of Race and Gender, 1852-1938 (2002) and is currently researching the Civil Rights Movement in South Bend, Indiana, from 1920 through the 1960s.

1. See, for example, Cynthia Fleming, Soon We Will Not Cry: The Liberation of Ruby Doris Smith Robinson (2000); Chana Kai Lee, For Freedom's Sake: The Life of Fannie Lou Hamer (2000); Barbara Ransby, Ella Baker and the Black Freedom Movement: A Radical Democratic Vision (2005); and Katherine Charron, Freedom's Teacher: The Life of Septima Clark (2012). 